\title{
Virtual Embassy Portal: The Future of Travel
}

\author{
Dalvin Hill ${ }^{1}$, Mohabbat Ahmadi ${ }^{2}$, \& Julaine Rigg ${ }^{3}$ \\ ${ }^{1}$ Information Technology, City University of New York - Stella and Charles Guttman Community College, New \\ York, NY, USA \\ ${ }^{2}$ Department Support Manager, University of California, Merced, CA, USA \\ Correspondence: \\ ${ }^{3}$ Department of Business Administration, Morgan State University, Baltimore, MD, USA \\ Correspondence: Dalvin Hill, Information Technology, City University of New York - Stella and Charles \\ Guttman Community College, New York, NY, USA.
}

Received: May 28, 2020

doi:10.5539/ibr.v13n7p199
Accepted: June 15, 2020

Online Published: June 23, 2020

URL: https://doi.org/10.5539/ibr.v13n7p199

\begin{abstract}
As the advent of travel continues to increase, tourism continues to expand, becoming the fastest growing economic activity globally. In order to travel internationally, one needs a passport and in many cases a visa is required. Currently, in order to apply for a visa, consumers have to complete and submit an application: online application completion and submission, visit a website to download the application form(s), physically visit an embassy/consulate, or utilize the services of a third party company to submit the application. Thereafter, there is a great chance the consumer might have to appear in person at the consulate/embassy for an in-person interview. There is a need to streamline the visa application process so that it is more efficient for both applicants as well as embassies.

This paper aims to fill the gap by introducing the Virtual Embassy concept. This concept promises to bring all embassies to an applicant's fingertip while making embassies more efficient in the process. The Virtual Embassy enables individuals to complete one application form which can be disseminated virtually to one or more consulate(s) of choice, without requiring extensive travel to embassies, or to manually complete multiple visa application forms.
\end{abstract}

Keywords: electronic visa, electronic tourist visa, e-visa, tourism visa, virtual embassy, virtual embassy portal

\section{Introduction}

With the recent trends toward globalization, there has been an unprecedented growth in the number of people traveling around the globe, for various reasons (Kopp, 2016). Over the decades, tourism has experienced continued growth and deepening diversification to become one of the fastest growing economic sectors in the world. Modern tourism is closely linked to development and encompasses a growing number of new destinations. These dynamics have turned tourism into a key driver for socio-economic progress (UNWTO Why Tourism, n.d). Although humanity has come a long way and the nature of traveling has evolved and has become much more convenient, we are still not capitalizing on the full potential of technology and the resources available at our fingertips.

Figure 1 depicts international tourists' arrival around the globe from 1995-2014 (Lock, 2019). There has been a steep year over year growth in traveling as seen in Figure 1. Over the past 20 years, the number of travellers doubled and according to IATA this trend is going to be consistent as we march towards globalization (IATA 20 Years Forecast, 2014). In more recent statistics and in agreement with Pearce's 2014 IATA 20 Years Forecast prediction, The World Tourism Organization, (UNWTO Why Tourism, n.d.) purports that:

The business volume of tourism equals or even surpasses that of oil exports, food products or automobiles. In 2017 International tourist arrivals grew by $7 \%$ to 1,323 million and generated US\$ 1.6 trillion in export earnings UNWTO forecasts a growth in international tourist arrivals of between $4 \%$ and $5 \%$ in 2018. By 2030, UNWTO forecasts international tourist arrivals to reach 1.8 billion. 


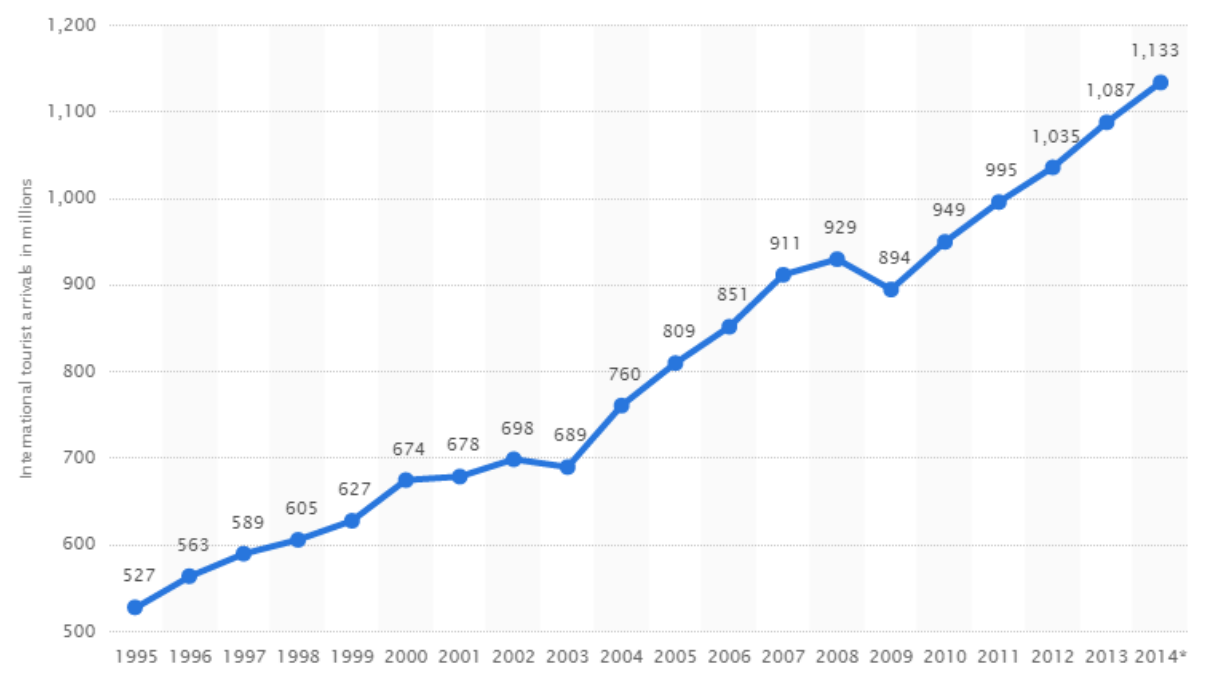

Figure 1. Number of international tourist arrivals worldwide from 1995 to 2014 (in millions)

\section{Visas, Challenges, and Tourism}

Several individuals have the financial resources to travel, but due to geographical determination they encounter grave challenges when they desire to travel. In many countries around the globe, people are required to travel extensively, sometimes within their city, country, neighbouring countries, or other non-adjacent countries to apply for a visa. Despite recent progress made in the area of visa facilitation, the current visa policies are still often inadequate and inefficient and are thus acknowledged to be an obstacle to tourism growth (Tourism Visa Openness Report, 2013). In 2012, for example, countries around the world, requested on average, that 63 percent of the world's population obtain a visa before initiating their international journey. Another 2 percent were at least allowed to apply for an eVisa, while 16 percent would be allowed to apply for a visa on arrival. Only 18 percent of the world's population would not require a visa at all when travelling for tourism purposes (Glaesser $\&$ Kester, 2013). The Merriam Webster Dictionary defines a visa as an endorsement made on a passport by the proper authorities denoting that it has been examined and that the bearer may proceed (Visa, n.d.). However, the means of acquiring visas are inefficient and pose various disadvantages pertaining to cost, time, and resources.

According to WTTC/UNWTO (The Impact of Visa Facilitation on Job Creation in the G20 Economies, 2012), while visas aim to fulfil the following functions: security, immigration control, limitation of duration of stay, to generate revenue, and to control carrying capacity and tourist demand, they also produce an impediment to travel and tourism, a sector which is an engine of growth for economies. For example, let us consider the process an Afghan citizen has to undergo when applying for a visa. If you are living anywhere in Afghanistan and you want to travel to China or Turkey, you must travel to the capital, Kabul, in order to get access to the Chinese consulate. If you wish to travel to Thailand, you need to travel to the neighbouring country Pakistan, to gain access to the Thai consulate. If your desire is to travel to Finland, you need to travel to India and stay for at least 15 days to get a positive/negative response, for people wishing to travel to Jamaica or Brazil, the process is even more cumbersome and time consuming.

If we attempt to calculate the cost incurred by each applicant, it is exhausting, time consuming, and discouraging. It is apparent that applicants incur stupendously high costs to travel to the capital cities to apply for a visa and wait to hear back from embassies/consulates. The cost becomes more horrendous when it involves traveling to other countries to apply for a visa, not to mention the cost associated with the involvement of middlemen who may serve as translators or visa application preparation centers. There could be cost savings if the visa application could be completed and submitted online from the convenience of the applicant's home. All that would be required is access to the Internet using a computer, tablet or a smartphone. With the current trend in technology, more and more users have access to the Internet, even in developing countries (Emerging Nations Embrace Internet, 2014).

The impact of cost is not only significant for individuals, but also presents a challenge to embassies. Consider, this can be extremely costly and time consuming for these consulates/embassies and can be problematic if a 
traveler needs to apply for a visa last minute. Of importance also, is the challenge of inadequate infrastructure and available personnel, especially in developing nations. Many of these nations are not equipped with the proper personnel, technology and infrastructure needed to issue documents in a timely and efficient manner (Securiport, n.d). It is almost impossible for a country to have a consulate in every nation worldwide. However, if these countries are provided with an option of establishing their embassies virtually via the Internet, it will be accessible to all, significantly improving the efficiency and effectiveness of their purpose. In 2014, a few weeks after the Turkish government launched the e-Visa application system, there was an increase in visa applications, going from a weekly average of 400 applications to over 1,500 in just a few days (Securiport, n.d). This is promising news since the projection is that the demand for traveling, specifically air travel, is favorable as seen in Figure 2 (Challenges of High Growth, 2015); the indicators show that travel is expected to double in the upcoming years.

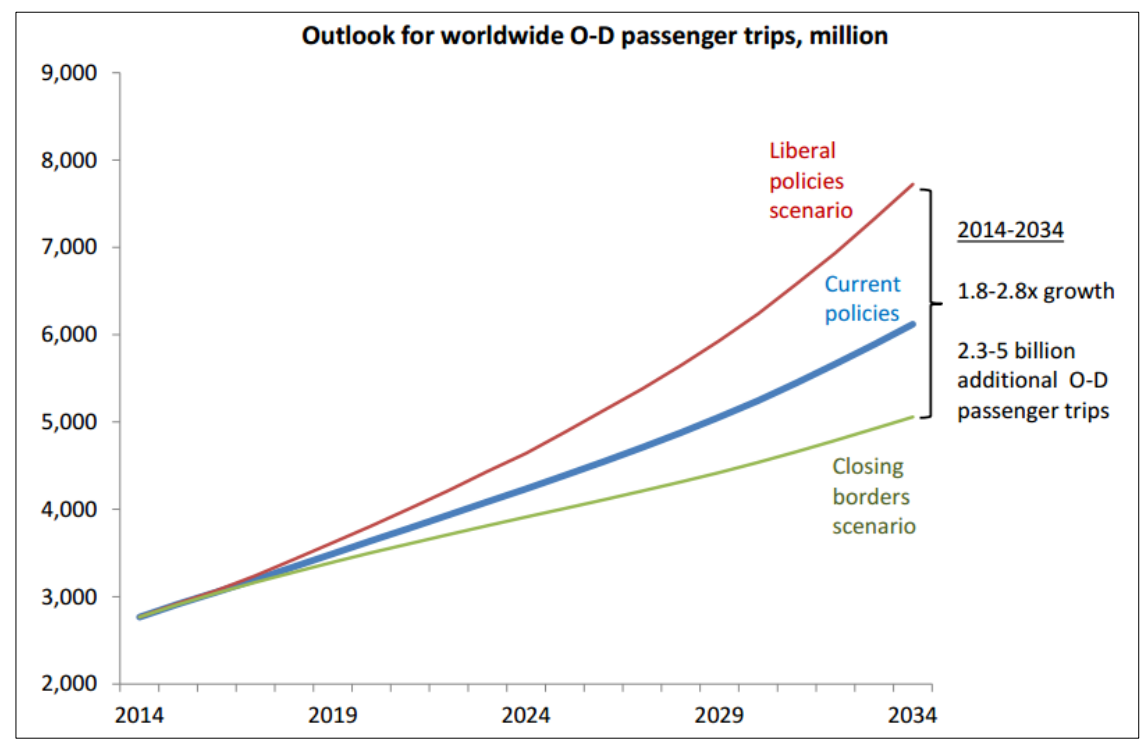

Figure 2. Outlook for Worldwide O-D Passenger Trips

\subsection{Electronic Tourist Visa/Electronic Visa}

After perusing various literature, the authors of this paper were not able to source a formal definition of an eVisa and as such, the decision was made to formulate a formal definition. An eVisa is an electronic-formatted visa authorization provided to foreigners that permit temporary travel to the issuing country without the need to visit a consulate/embassy. Several countries have successfully implemented Electronic Tourist Visas (eTVs). eTVs are applied for (and if approved, issued) online without the need to have a label or stamped visa added to the applicant's passport. They are also referred to an Electronic Visas (EVs) and Electronic Travel Authority (ETA); throughout this paper, they will all be referred to as eTVs. There has been a growing trend as it pertains to the number of countries that are participants in the issuance of ETVs.

It is imperative to note that not all countries participate in the issuance of eTVs, and likewise not all individuals (contingent on passport/country) are eligible to apply for an eTV. The eVisa application process must be completed and submitted online, and the results are returned to the applicant in an electronic format. If the eVisa is granted, the applicant can then print the eVisa and bring it along with his/her passport at the time of travel to the issuing country. Similarly, if the eVisa application is denied, a rejection notice would be sent (to the applicant and it means the applicant would not be able to travel to the country from which the denial notice was received). eVisas eliminate the need to dedicate a page in a passport that would previously be used for the insertion of a visa.

\subsubsection{The eTV Application Process}

To better understand the eTV application process, a sample of four applications were examined. The eTVs examined were that of India, Turkey, Sri Lanka, and Australia. The accompanying paragraphs seek to document the application process of these respective countries. 


\subsubsection{India eTV}

"The India eTV is an e-Visa for travel to India for tourism. The Indian Visa on Arrival eTV is issued on-line; it is not necessary to submit an original passport or other documents for processing" (Government of India e-Visa, n.d.). Figure 3 provides a pictorial representation of the Indian E-Tourist Visa Application Process (India Visa Online, n.d.). First the applicant visits the website and completes the application form, uploads a photograph and a copy of the passport information page. This is followed by the payment of the visa fee which can be completed by using a credit or debit card. The complete application form is then transmitted to the Indian Consulate/Embassy in which the information is scrutinized, and a decision is made. As seen in step three, an email is sent notifying the applicant of the approval (or rejection) notice. If approved, the applicant can print the eTV and then get prepared to fly to India with his/her passport and a printed copy of the eTV.

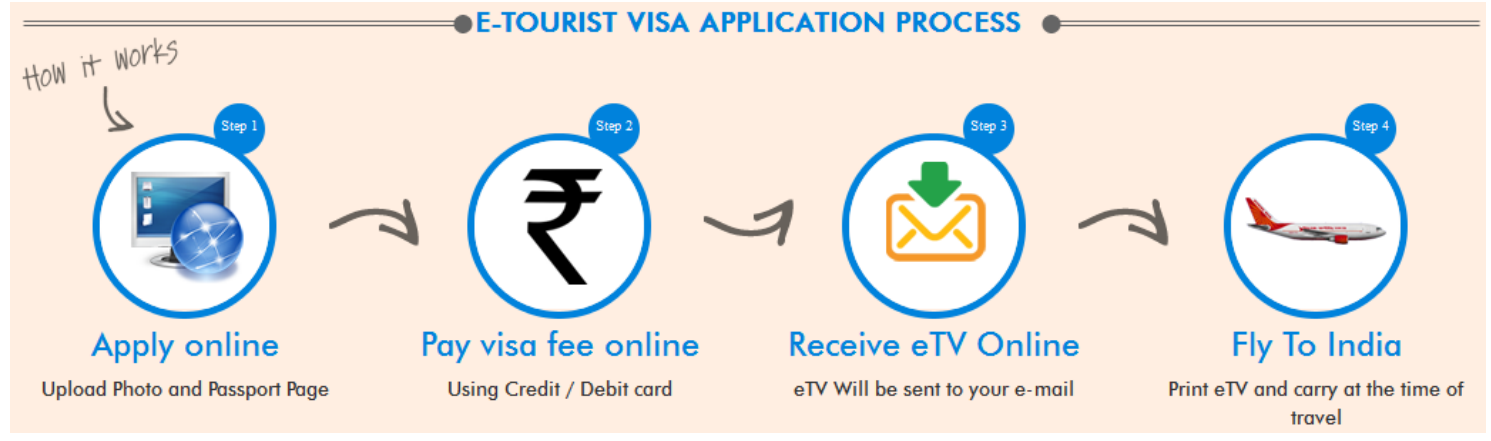

Figure 3. Indian E-Tourist Visa Application Process

\subsubsection{Turkey e-Visa}

Turkey has an e-Visa and it is defined as "an official document permitting entry into and travel within Turkey" (Republic of Turkey Electronic Visa Application System, n.d.). Applicants can visit the e-Visa portal to complete the visa application and submit any additional supporting documents that are required. An acknowledgement email is then sent to the applicant using the supplied email address, notifying the applicant of the submission of the application. Within hours, a second email is sent indicating a request for additional information, a rejection notice, or the approved e-Visa. If the e-Visa is approved, the applicant can then print the e-Visa and travel to Turkey along with his/her passport.

\subsubsection{Sri Lanka ETA}

Individuals planning to visit Sri Lanka for vacation, short business trip, or as transit passengers can apply for an ETA. The application is submitted online, and an acknowledgement of the application is sent to the applicant via email. Then the applicant will "receive ETA approval or a referral notice. If an approval notice is sent to the applicant via email, the applicant can print the ETA and then travel to Sri Lanka. If a referral notice is served, you may contact Department of Immigration and Emigration for the necessary ETA" (Rukmal, n.d.).

\subsubsection{Australia ETA}

Australia's E-Visa is called Electronic Travel Authority (ETA). It is defined as "an electronically stored authority for travel to Australia which: replaces the visa label or stamp in a passport; it is available through participating travel agencies, airlines and the Internet; does not require an application form; enables passengers to be processed quickly on arrival in Australia" (Australia's ETAS: Electronic Travel Authority System, Australian Government Electronic Travel Authority, n.d.).

\section{Motivation}

With recent trend towards globalization, there is an unprecedented demand for tourism consumption and the demand for travel has increased unprecedentedly. According to Cook, Hsu and Taylor, (2018), "Over the past six decades, tourism has experienced continued expansion and diversification, to become one of the largest and fastest-growing economic sector of the world" (p.4). The future prospects for tourism are brighter than ever as people continue to travel for work or pleasure. Growth projections show that tourism will support almost 350 million jobs worldwide by 2025 and increase of over 70 million jobs when compared to 2015 (Cook et al., 2018, p.4). With these expected growths and impacts, the need for visa efficiencies will become even more paramount to growth and development. According to the Tourism Visa Openness Report, (2013), "visa policies are among 
the most important governmental formalities influencing international tourism" (p.4).

With a higher desire to travel comes the notion of increased visa solicitation. Even though the recent strides towards eVisas have benefitted tourism facilitation and the increased use of eVisas, there remains a serious lack of inefficiencies with regards to resources, cost, and time, which if improved could have a positive impact globally on economic growth and development. As such, the authors aim to fill this gap by proposing a solution that would reduce the amount of time, cost, and inconvenience required to apply for one or multiple visas. The proposed solution (Virtual Embassy Portal, which will be discussed later in the paper) is comparable to the Common Application. Common Application is one such entity that enables prospective college/university applicants to enter their information once and utilize it to apply for one or more institution(s). A similar platform, The Virtual Embassy could assist applicants in their visa application. It would be opportune if a visa applicant could enter their information into one portal, and tweak or reuse it to apply for additional visas.

\subsection{The Common Application}

The Common Application is an online portal that is comprised of over 600 colleges and universities around the world. An applicant (potential student) can visit the Common Application portal, and apply to one, many, or all the registered institutions by completing a single universal application. About 1,000,000 students utilize this portal each year to submit over 3,500,000 applications. The Common Application boasts that applicants can "Work Smarter: there is no need to repeat your applicant details for every college on your list. Enter your information one time and share it across all of your schools" (Apply to College with Common App, n.d.).

From the Common Application website, the applicant can search for a college/university based on various search options such as institution name, location, country, public/private, application deadline, and so on. Once the search result is displayed, the applicant can read the profile of the institution, and find other pertinent information such as the institution's address, email address, and phone number. The applicant can then apply for one or more institution(s) of choice. The portal can also be used to send recommendation requests to counselors, teachers, and others. All uploaded documents will then be sent to the institution(s) selected by the applicant. As such, there is no need to complete separate applications for various institutions, which generally would have looked differently, but requiring similar information.

\subsection{The Nature of Visa Forms}

Most visa application forms are comprised of almost identical set of questions. Table 1 is a matrix that was compiled from examining the visa application forms of Afghanistan (Embassy of Afghanistan Visa Applications, n.d.), China (Embassy of the People's Republic of China in the United States of America, n.d.), India (Government of India e-Visa, n.d.), Sri Lanka (Sri Lanka Electronic Travel Authorization System Online Visa Application, n.d.) and United States (U.S. Department of State Consular Electronic Application Center, n.d.). These countries were selected as a sample on the premise that they are a representation of first, second, and third world countries. Each of the application form was inspected to determine the data required of applicants. It is imperative to note that only non-immigrant/tourist visa were examined. If a data is required on an application form, it is marked with an " $\mathrm{X}$ " to indicate such. If the cell is left blank, it means the data is not a required or it is an optional field.

Nonetheless, one critical observation is that these application forms require more or less the same information from applicants. The difference in requirement is miniscule and supports the notion that the Virtual Embassy technology could be a great alternative for disseminating information to the various embassies/consulates (with the initiation and permission of the applicant). There might be a slight variation in the application forms, as it is dependent on the country in which you reside or are applying. 
Table 1. Visa Application Information Matrix

\begin{tabular}{|c|c|c|c|c|c|}
\hline Requested Data & $\begin{array}{l}\text { Afghanistan } \\
\text { (Paper } \\
\text { Based } \\
\text { Application } \\
\text { Available } \\
\text { Online) }\end{array}$ & $\begin{array}{l}\text { China } \\
\text { (Paper } \\
\text { Based } \\
\text { Application } \\
\text { Available } \\
\text { Online) }\end{array}$ & $\begin{array}{l}\text { India } \\
\text { (Electronic } \\
\text { Tourist } \\
\text { Authorizati } \\
\text { on System) }\end{array}$ & $\begin{array}{l}\text { Sri Lanka } \\
\text { (Electronic } \\
\text { Tourist } \\
\text { Authorization } \\
\text { System) }\end{array}$ & $\begin{array}{l}\text { United States } \\
\text { (Online } \\
\text { Application) }\end{array}$ \\
\hline Title & $\mathrm{X}$ & & & $\mathrm{X}$ & \\
\hline $\begin{array}{l}\text { Applicant's Name (Given, Middle, } \\
\text { Last) }\end{array}$ & $\mathrm{X}$ & $\mathrm{X}$ & $\mathrm{X}$ & $\mathrm{X}$ & $\mathrm{X}$ \\
\hline Date of Birth & $\mathrm{X}$ & $\mathrm{X}$ & $\mathrm{X}$ & $\mathrm{X}$ & $\mathrm{X}$ \\
\hline Gender/Sex & $\mathrm{X}$ & $\mathrm{X}$ & $\mathrm{X}$ & $\mathrm{X}$ & $\mathrm{X}$ \\
\hline Marital Status & $\mathrm{X}$ & $\mathrm{X}$ & $\mathrm{X}$ & & $\mathrm{X}$ \\
\hline Place of Birth & $\mathrm{X}$ & $\mathrm{X}$ & $\mathrm{X}$ & $\mathrm{X}$ & $\mathrm{X}$ \\
\hline Child/Children & $\mathrm{X}$ & $\mathrm{X}$ & & $\mathrm{X}$ & \\
\hline Country of Residence & $\mathrm{X}$ & $\mathrm{X}$ & $\mathrm{X}$ & & \\
\hline Country of Origin/Nationality & $\mathrm{X}$ & $\mathrm{X}$ & $\mathrm{X}$ & $\mathrm{X}$ & $\mathrm{X}$ \\
\hline Other Nationality & $\mathrm{X}$ & $\mathrm{X}$ & $\mathrm{X}$ & $\mathrm{X}$ & $\mathrm{X}$ \\
\hline National ID Number & & $\mathrm{X}$ & $\mathrm{X}$ & & $\mathrm{X}$ \\
\hline Home Address/Mailing Address & $\mathrm{X}$ & $\mathrm{X}$ & $\mathrm{X}$ & $\mathrm{X}$ & $\mathrm{X}$ \\
\hline Phone Number & $\mathrm{X}$ & $\mathrm{X}$ & $\mathrm{X}$ & $\mathrm{X}$ & $\mathrm{X}$ \\
\hline Email Address & $\mathrm{X}$ & $\mathrm{X}$ & $\mathrm{X}$ & $\mathrm{X}$ & $\mathrm{X}$ \\
\hline Passport Number & $\mathrm{X}$ & $\mathrm{X}$ & $\mathrm{X}$ & $\mathrm{X}$ & $\mathrm{X}$ \\
\hline Passport Expiration Date & $\mathrm{X}$ & $\mathrm{X}$ & $\mathrm{X}$ & $\mathrm{X}$ & $\mathrm{X}$ \\
\hline $\begin{array}{l}\text { Other Passport Details (Place of } \\
\text { Issue, Country) }\end{array}$ & $\mathrm{X}$ & $\mathrm{X}$ & $\mathrm{X}$ & & $\mathrm{X}$ \\
\hline Purpose of Travel & $\mathrm{X}$ & $\mathrm{X}$ & & $\mathrm{X}$ & $\mathrm{X}$ \\
\hline Intended Date of Travel & $\mathrm{X}$ & $\mathrm{X}$ & $\mathrm{X}$ & $\mathrm{X}$ & $\mathrm{X}$ \\
\hline $\begin{array}{l}\text { Details of Travel (Address You Plan } \\
\text { to Stay, Length of Stay, Source of } \\
\text { Funds, Others Traveling With You) }\end{array}$ & $\mathrm{X}$ & $\mathrm{X}$ & $\mathrm{X}$ & $\mathrm{X}$ & $\mathrm{X}$ \\
\hline $\begin{array}{l}\text { Have You Ever Traveled to this } \\
\text { Country Before }\end{array}$ & $\mathrm{X}$ & & $\mathrm{X}$ & & $\mathrm{X}$ \\
\hline Religion & & & $\mathrm{X}$ & & \\
\hline $\begin{array}{l}\text { Have You Ever Been Issued a Visa } \\
\text { For This Country Before }\end{array}$ & $\mathrm{X}$ & $\mathrm{X}$ & & $\mathrm{X}$ & $\mathrm{X}$ \\
\hline $\begin{array}{l}\text { Refused a Visa For This Country } \\
\text { Before }\end{array}$ & $\mathrm{X}$ & $\mathrm{X}$ & & & $\mathrm{X}$ \\
\hline Other Countries Traveled & & $\mathrm{X}$ & $\mathrm{X}$ & & \\
\hline Immigrant Petition Underway & & & & & $\mathrm{X}$ \\
\hline $\begin{array}{lll}\text { Contact } & \text { Information } & \text { of } \\
\text { Family/Friends in Destination } & \\
\end{array}$ & & $\mathrm{X}$ & $\mathrm{X}$ & $\mathrm{X}$ & $\mathrm{X}$ \\
\hline Father's Name (Given and Surname) & $\mathrm{X}$ & & $\mathrm{X}$ & & $\mathrm{X}$ \\
\hline $\begin{array}{llll}\text { Mother's } & \text { Name } & \text { (Given } & \text { and } \\
\text { Surnames) }\end{array}$ & & & $\mathrm{X}$ & & $\mathrm{X}$ \\
\hline $\begin{array}{l}\text { Work/Education/Training } \\
\text { Information }\end{array}$ & $\mathrm{X}$ & $\mathrm{X}$ & $\mathrm{X}$ & $\mathrm{X}$ & $\mathrm{X}$ \\
\hline $\begin{array}{lll}\text { Security } & \text { and } & \text { Background } \\
\text { Information }\end{array}$ & $\mathrm{X}$ & $\mathrm{X}$ & & & $\mathrm{X}$ \\
\hline Submission of Photo & $\mathrm{X}$ & $\mathrm{X}$ & $\mathrm{X}$ & & $\mathrm{X}$ \\
\hline Signature & $\mathrm{X}$ & $\mathrm{X}$ & & & $\mathrm{X}$ \\
\hline
\end{tabular}

\section{Virtual Embassy Portal}

In order to utilize the Virtual Embassy Portal, an applicant visits the portal and create an account. Once the account containing an email address, username and password has been created, an application form needs to be filled out which is similar in nature to that of a visa form at a consulate. These form fields are also outlined in Table 1. The completed application form is stored in a secured database and can be accessed, edited or deleted at any time by the applicant. The applicant can also upload supporting documents such as employment letters, bank statements, photographs and itinerary, to name a few. The next step in the process is for the applicant to search for one or more country(ies) that s/he wants to apply for a visa(s). The applicant can then apply for said visa(s) using the stored information that was entered in the account at creation of the Virtual Embassy Portal. Instead of creating a separate application for each of the 196 countries, the Virtual Embassy Portal is proposing a one stop 
shop in which only one application will be created, and the information will be used to apply to any and all participating consulates. As outlined in Table 1, the information needed by each consulate is almost identical, so it is indicative that one application form can be created and used to populate the forms of any consulate the applicant wishes to apply for a visa.

Figure 4 illustrates the Virtual Embassy Portal concept. Let's examine the following scenario: Applicant A can visit the Virtual Embassy Portal and create a profile, proceeded by the application form. This information is stored in a secured database and can be accessed only by Applicant after s/he logs in. Applicant A can then search the Virtual Embassy Portal for a country that s/he wishes to apply for a visa. In this instance, let's say Applicant A wishes to search for India, this can be done using the search menu; once the country is found, it can be selected. The information is then transferred from the Virtual Embassy Portal and used to auto-fill the respective fields on the form(s) of the Indian consulate via a secured medium. The applicant is then able to review his/her information (and make edits if it is required) and then submit the completed application form to the Indian consulate.

It is expected that some information such as marital status, name change, number of children, address, among others will be updated from time to time within the Virtual Embassy Portal. The consumer can make such edits by logging in with his/her username and password. Again, there would be a one-to-many relationship since the applicant could update the information once which then can be used to apply to many embassies. Once an applicant has identified a country in which s/he wishes to obtain a visa for travel, there might be additional, yet minimal information that is needed from the applicant. For example, almost all applicants will be asked about the purpose of their trip. That is information that will be specific for each country so the applicant will have to provide an answer for the specific visa application. Also, some countries ask unique questions as it pertains to political and religious concerns. Once all the information is entered by the applicant, the information (that was previously entered in the Virtual Embassy Portal) will then be securely transferred to the consulate's application form. Prior to submitting the application form to the consulate, the applicant will have the opportunity to review the information and make relevant changes; information such as applicant's name, date of birth, place of birth, among others will not be editable.

The authors of this paper are of the belief that most consulates will not be willing to modify their existing application forms to facilitate "a universal application form" such as the one developed by the Virtual Embassy. On a promising note, our proposed solution is not intended to replace the forms or systems currently in use by consulates. Instead, our system intends to coexist with the processes and systems of the embassies. Neither will it interfere with the existing system or outcome of the visa application. Our system will capture details from applicants and then render the required information to the consulate. We intend to strategically utilize XML functionality to populate the application forms of the desired consulate. This requires our system to accurately match a field name in our system to that on the application form of each consulate. For example, one embassy might refer to a field as <<first name〉>, while another might refer to the identical field as <<christian name〉>. By mapping the fields of each consulate to the corresponding field of the Virtual Embassy Portal, it enforces accuracy as it pertains to the completion of the application form. Our system intends to deliver the relevant application forms in a digital format and does not require a data entry clerk at the consulate to manually re-enter data into their systems. Most importantly, our system will extend the accessibility of consulates so that everyone can have access contingent on them having access to a computer and the Internet to submit a visa application if they so desire.

One might think the implementation of the Virtual Embassy Portal ideology could be a potential security threat to some nations (as it might be perceived that since consulates might be more accessible, more individuals might get visas). However, this technology does not guarantee that the applicant will be issued a visa. Instead, it extends the accessibility of embassies and consulates to anyone who has access to a computer and the Internet. The Virtual Embassy will not impact the decision making of consulates, and as such, the ultimate decision is that of the respective consulate. This platform will make it easier (especially if the applicant does not meet the requirements of a visa for a given country), less expensive, and more convenient for people to apply for visas. 


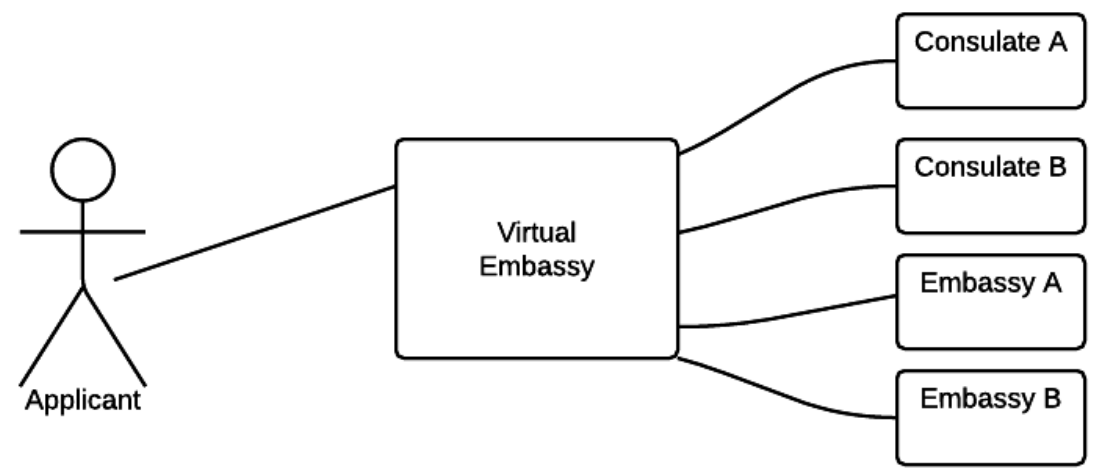

Figure 4. The Virtual Embassy Portal Concept

\section{Conclusion and Future Work}

The virtual embassy proposed by the authors presents a more efficient way for countries to facilitate the processing of eVisas. The Virtual Embassy Portal is a proposed system in which a consumer can visit one website and have access to the various consulates around the world. The consumer will be able to find answers pertaining to visa requirements, eligibility, and guidelines for participating countries. Without the Virtual Embassy Portal, if a consumer wishes to travel to one or more country, research has to be done individually (by visiting the website of each consulate) to determine if a visa is needed. If a visa is needed, the applicant is tasked with locating the pertinent consulate to apply in person, complete the paperwork online and mail it in/appear in person, apply via a third-party agency, or apply online as is the case with eTVs. Nonetheless, it takes an incredible amount of time to conduct the research and to apply for a visa. The Virtual Embassy can reduce the amount of time taken to visit the website of numerous consulates, commute time, cost associated with printing the relevant paperwork, along with the time needed to complete separate visa application forms for different countries.

As it pertains to future steps, the authors of this paper will need to further analyze the websites of all consulates to determine the names of each field listed on the application form. It will be easier to parse websites that currently accept eTVs since the fields on those forms will have a unique name. For the countries that are not participating with eTVs, we will have to generate field names for their paper-based form fields and assume that the consulates will be receptive to using these field names. Then we will be required to map the consulate website form field names to that of the Virtual Embassy Portal form field names. A major hurdle that we can foresee is that we may have to assist some of these consulates with the creation of a website that can accept an online application form and a backend database to store applicant data. Once a consulate is thus equipped, we need to have them identify a website administrator who will then be tasked with setting up a consulate administrator account on the Virtual Embassy Portal. From this administrator login, the consulate will be able to see the application forms of applicants. We foresee a bit of resistance from consulates, but it is our intention to host various informational sessions to demonstrate the rationale behind the Virtual Embassy Portal.

\section{References}

Apply to college with Common App, Your future Starts here. (n.d.). Retrieved October 24, 2019, from http://www.commonapp.org/

Australian Government Electronic Travel Authority. (n.d.). Retrieved October 23, 2019, from https://www.eta.homeaffairs.gov.au/ETAS3/etas.WSA Winner 2013: Electronic Travel Authority ETA and Integrated Border Management System IBMSThe

Challenges of High Growth: Global Aviation Outlook. (2015). Retrieved September 15, 2016, from https://cpb-us-e1.wpmucdn.com/blog.umd.edu/dist/9/604/files/2019/02/2015_GC_-28wsgxc.pdf

Cook, R. A., Taylor, L. L., \& Hsu, C. H. C. (2018). Tourism: the business of hospitality and travel.

Embassy of Afghanistan Visa Applications. (n.d.). Retrieved October 24, 2019, from https://www.afgvisa.com/

Embassy of the People's Republic of China in the United States of America. (n.d.). Retrieved October 24, 2019, 
from http://www.china-embassy.org/eng/visas/fd/

Emerging Nations Embrace Internet, Mobile Technology. (2014). Retrieved February 13, 2014, from http://www.pewglobal.org/2014/02/13/emerging-nations-embrace-internet-mobile-technology/

Glaesser, D., \& Kester, J. (2013). Visa Facilitation: Stimulating Economic Growth and Development through Tourism. Retrieved October 15, 2019, from https://umih.fr/export/sites/default/content/media/pdf/Etudes-CHRD-tourisme/WEF_TT_Competitiveness_ Report_2013.pdf\#page=81

Government of India e-Visa. (n.d.). Retrieved October 23, 2019, from https://indianvisaonline.gov.in/visa/tvoa.html

IATA 20 Years Forecast. (2014). Retrieved September 8, 2016, from https://www.iata.org/whatwedo/Documents/economics/20yearsForecast-GAD2014-Athens-Nov2014-BP.pd $\mathrm{f}$

India Visa Online. (n.d.). Retrieved October 23, 2019, from https://www.indianevisaservice.org.in/?gclid=EAIaIQobChMIo8WKnLmh5QIVFKSzCh3J7QG-EAAYAS AAEgIphPD_BwE

Kopp, C. M. (2016). Learn About Globalization. Retrieved November 1, 2019, from http://www.investopedia.com/terms/g/globalization.asp

Lock, S. (2019, October 8). International tourist arrivals worldwide 2018. Retrieved October 15, 2019, from http://www.statista.com/statistics/209334/total-number-of-international-tourist-arrivals/

Republic of Turkey Electronic Visa Application System. (n.d.). Retrieved October 23, 2019, from https://www.evisa.gov.tr/en/info/what-is-an-e-visa/

Rukmal, N. (n.d.). Sri Lanka Electronic Travel Authorization System Online Visa Application. Retrieved October 23, 2019, from http://www.eta.gov.lk/slvisa/visainfo/apply.jsp;jsessionid=bGqVW27Gt27CnnW7ymHKyFzGTgk1qLLkJm 1PL31X7vJcG5SwzrKp!1844224897?locale=en_US

Securiport - eVisa solutions provide a faster, smarter, safer way to travel, benefiting tourism and local economies. (n.d.). Retrieved April 4, 2015, from http://www.securiport.com/wp-content/uploads/Securiport-eVisa-Whitepaper.pdf

Sri Lanka Electronic Travel Authorization System. (n.d.). Retrieved October 24, 2019, from https://eta.gov.lk/etaslvisa/etaNavServ?payType $=1$

The impact of visa facilitation on job creation in the G20 economies. Report prepared for the 4th T20 ministries meeting, Mexico, 15-16th May 2012. (2012). Retrieved October 10, 2019, from https://www.wttc.org/-/media/files/reports/policy-research/visa_facilitation-g20.pdf

Tourism visa openness report: Visa facilitation as a means to stimulate economic growth. (2013). Retrieved April 13, 2016, from http://cf.cdn.unwto.org/sites/all/files/docpdf/tourismvisaopennessreport23august20132.pdf

U.S. Department of State Consular Electronic Application Center. (n.d.). Retrieved October 24, 2019, from https://ceac.state.gov/GenNIV/Default.aspx

UNWTO Why tourism? (n.d.). Retrieved August 15, 2017, from http://www2.unwto.org/content/why-tourism

Visa. (n.d.). Retrieved September 8, 2016, from https://www.merriam-webster.com/dictionary/visa

\section{Copyrights}

Copyright for this article is retained by the author(s), with first publication rights granted to the journal.

This is an open-access article distributed under the terms and conditions of the Creative Commons Attribution license (http://creativecommons.org/licenses/by/4.0/). 